\title{
SISTEM PENDUKUNG KEPUTUSAN PEMILIHAN DOSEN BERPRESTASI MENGGUNAKAN METODE ANALYTICAL HIERARCHY PROCESS (AHP)
}

\author{
${ }^{[1]}$ Wahyu Dwi Puspitasari, ${ }^{[2]}$ D. Kharidatul Ilmi \\ ${ }^{[1],[2]}$ Universitas Islam Balitar
}

\begin{abstract}
Abstrak : Pemilihan dosen berprestasi di Universitas Islam Balitar berkaitan dengan adanya pemilihan dosen berprestasi yang diadakan oleh Kopertis Wilayah VII, sehingga universitas akan ikut berpartisipasi untuk mengirim perwakilan dosen ke tingkat Kopertis. Kriteria yang digunakan dalam pemilihan dosen berprestasi adalah kriteria prestasi unggul dan karya tridarma. Subkriteria untuk prestasi unggul adalah penelitian, pendidikan dan pengabdian. Subkriteria untuk karya tridarma adalah penelitian, pendidikan, pengabdian dan penunjang lainnya. Sistem pendukung keputusan pemilihan dosen berprestasi ini menggunakan metode Analytical Hierarchy Process (AHP) yang dilakukan dengan membuat nilai matriks berpasangan untuk masing-masing kriteria. Nilai dari matriks berpasangan hasilnya harus konsisten. Data penilaian dosen akan dihitung dengan nilai matriks berpasangan dan hasil dari perhitungan tersebut akan muncul berbentuk rating nilai. Rating nilai dosen yang tertinggi, berhak untuk menjadi dosen berprestasi di Universitas Islam Balitar.
\end{abstract}

Kata kunci : Sistem Pendukung Keputusan, Metode Analytical Hierarchy Process (AHP), Pemilihan Dosen Berprestasi.

\section{Pendahuluan}

\section{a. Latar Belakang}

Pemilihan dosen berprestasi adalah memberikan pengakuan dan penghargaan kepada dosen yang dapat menjadi salah satu cara dalam pengembangan manajemen akademik, sehingga bermanfaat bagi kemajuan peningkatan kualitas akademik dan kelembagaan. Berkaitan dengan adanya pemilihan dosen berprestasi yang diadakan oleh Kopertis Wilayah VII, Universitas Islam Balitar akan ikut berpartisipasi untuk mengirim perwakilan dosen berprestasi ke tingkat Kopertis. Sehingga perlu dibuat sebuah sistem pendukung keputusan untuk membantu proses pemilihan dosen berprestasi di Fakultas Teknologi Informasi Universitas Islam Balitar.

b. Rumusan Masalah

1. Bagaimana merancang sistem pendukung keputusan pemilihan dosen berprestasi di FTI Universitas Islam Balitar?

2. Bagaimana menerapkan metode Analytical Hierarchy Process (AHP) dalam mengambil suatu keputusan pemilihan dosen berprestasi di FTI Universitas Islam Balitar?

3. Bagaimana implementasi pada sistem pendukung keputusan pemilihan dosen berprestasi di FTI Universitas Islam Balitar? 


\section{c. Batasan Masalah}

1. Bahasa pemrograman yang digunakan adalah Web PHP dengan menggunakan database MySQL.

2. Text editor yang digunakan untuk mengedit source code menggunakan notepad++.

3. Sistem pendukung keputusan pemilihan dosen berprestasi tidak online, karena pengguna sistem dalam 1 (satu) instansi.

4. Kriteria dalam sistem ini adalah prestasi unggul dan karya tridarma. Subkriteria untuk prestasi unggul adalah penelitian, pendidikan dan pengabdian. Subkriteria untuk karya tridarma adalah penelitian, pendidikan, pengabdian dan penunjang lainnya. Isian kriteria disesuaikan dengan keputusan Kopertis Wilayah VII tentang Pemilihan Dosen Berprestasi tahun 2015.

5. Sistem pendukung keputusan pemilihan dosen berprestasi menghasilkan output berupa rating nilai.

6. Pengguna sistem pendukung keputusan pemilihan dosen berprestasi adalah admin dan kaprodi.

\section{LANDASAN TEORI}

\section{a. Dosen}

Dosen adalah pendidik profesional dan ilmuwan dengan tugas utama mentransformasikan, mengembangkan, dan menyebarluaskan ilmu pengetahuan, teknologi, dan seni melalui pendidikan, penelitian, dan pengabdian kepada masyarakat (Undang-undang Republik Indonesia Nomor 14 Tahun 2005 Tentang Guru dan Dosen).

\section{b. Dosen berprestasi}

Dosen berprestasi adalah dosen yang dalam tiga tahun terakhir memiliki prestasi yang bermanfaat dan dapat dibanggakan Perguruan Tinggi asal, serta diakui pada skala nasional atau internasional (Kementerian Riset Teknologi dan Pendidikan Tinggi Direktorat Jenderal Pendidikan Tinggi Direktorat Pendidik dan Tenaga Kependidikan, 2015).

\section{c. Kriteria Pemilihan Dosen Berprestasi}

1. Karya Prestasi Unggul, dengan nilai kumulatif $75 \%$

a. Penelitian antara lain dalam bentuk:

1) Hak atas Kekayaan Intelektual

2) Tulisan/ publikasi pada jurnal nasional yang terakreditasi maupun jurnal internasional

3) Model/ prototipe/ sistem yang bermanfaat bagi masyarakat

4) Bahan ajar berbasis hasil penelitian

5) Karya tulis ilmiah yang disajikan pada seminar-seminar ilmiah di tingkat nasional/ internasional

6) Karya seni yang dipergelarkan/ dipamerkan pada forum nasional atau internasional 
b. Pendidikan dan Pembelajaran

1) Buku ajar/ diktat/ penuntun praktikum/ metode diskusi

2) Metode/ teknologi pembelajaran yang kreatif

3) Metode/ model pembimbingan bagi asisten atau dosen muda

4) Metode/model pemotivasian pembelajaran kepada mahasiswa

c. Pengabdian pada Masyarakat antara lain dalam bentuk:

1) Konsep penataan lingkungan, penerapan teknologi, dan pemberdayaan masyarakat

2) Model pengembangan wilayah

3) Model pemberdayaan masyarakat

4) Model pengembangan kemitraan

5) Model penataan kelembagaan

6) Model penyebaran atau difusi temuan-temuan baru

7) Modul pengembangan sumberdaya manusia atau sumber daya lainnya

8) Publikasi dalam pengabdian kepada masyarakat

9) Konsultasi bagi pengembangan dunia bisnis dan non-bisnis

Bobot penilaian prestasi unggul sebagai berikut:

a. Pendidikan dan pembelajaran $\quad: 35 \%$

b. Penelitian $: 45 \%$

c. Pengabdian pada masyarakat $\quad: 20 \%$

2. Karya Tridarma Perguruan Tinggi, dengan nilai kumulatif $25 \%$

Kegiatan tridarma Perguruan Tinggi dinilai berdasarkan karya yang dihasilkan dalam kurun waktu tiga tahun terakhir.

a. Penelitian

1) Penelitian yang dipublikasikan (buku, jurnal, seminar)

2) Membuat rancangan dan karya yang dipatenkan

3) Membuat rancangan dan karya teknologi/ karya seni monumental/ seni pertunjukan/ karya sastra

b. Pendidikan dan Pembelajaran

1) Memperoleh ijasah $\mathrm{S} 3 / \mathrm{S} 2$

2) Mengajar berapa banyak SKS

3) Membimbing: seminar mahasiswa, KKN, praktik, kerja lapangan, magang

4) Membimbing disertasi/ tesis/ skripsi/ tugas akhir/ lap akhir

5) Mengembangkan bahan ajar (buku ajar, diktat, modul, penuntun praktikum, praktik)

c. Pengabdian Masyarakat

1) Judul materi pelatihan

2) Judul materi pelayanan/ konsultasi

3) Judul kegiatan pengembangan hasil pendidikan/ penelitian

d. Penunjang Lainnya

1) Menjadi anggota dalam badan perguruan, lembaga pemerintah, organisasi profesi, antar lembaga, delegasi nasional di pertemuan internasional 
2) Berperan aktif dalam pertemuan ilmiah

3) Mempunyai prestasi di bidang olah raga/ humaniora

Bobot penilaian tridarma Perguruan Tinggi dan penunjang sebagai berikut:

a. Pendidikan dan pembelajaran $: 35 \%$

b. Penelitian $: 45 \%$

c. Pengabdian pada masyarakat $\quad: 10 \%$

d. Kegiatan penunjang tridarma $: 10 \%$

(Kementerian Riset Teknologi dan Pendidikan Tinggi Direktorat Jenderal Pendidikan Tinggi Direktorat Pendidik dan Tenaga Kependidikan, 2015).

\section{d. Sistem Pendukung Keputusan}

Sistem pendukung keputusan atau Decision Support Sistem (DSS) adalah sebuah sistem yang dimaksudkan untuk mendukung para pengambil keputusan manajerial dalam situasi keputusan semiterstruktur (Turban, 2005).

\section{e. Analytical Hierrchy Process (AHP)}

Metode Analytical Hierrchy Process (AHP) dapat memecahkan masalah kompleks, dimana kriteria yang diambil cukup banyak, struktur masalah yang belum jelas, dan ketidakpastian tersedianya data statistik yang akurat. Dalam menyelesaikan permasalahan dengan Analytical Hierrchy Process (AHP) ada beberapa prinsip yang harus dipahami, diantaranya adalah (Kusrini, 2007):

\section{Membuat Hierarki}

Menetapkan suatu tujuan (goal), selanjutnya diuraikan ke dalam kriteria, kemudian menentukan alternatif atau pilihan penyelesaian masalah.

2. Penentuan Prioritas Elemen

Membuat matriks perbandingan ber-pasangan untuk membandingkan elemenelemen secara berpasangan sesuai dengan kriteria yang diberikan. Perbandingan berpasangan menurut Saaty (1980) bisa diukur menggunakan tabel 1:

TABEL 1.

SKALA PERBANDINGAN BERPASANGAN

\begin{tabular}{cl}
\hline Skala & \\
\hline 1 & Kedua elemen sama pentingnya \\
3 & Elemen yang satu sedikit lebih penting daripada elemen yang \\
& lainnya \\
5 & Elemen yang satu lebih penting daripada elemen lainnya \\
7 & Satu elemen jelas lebih mutlak penting daripada elemen lainnya \\
9 & Satu elemen mutlak penting daripada elemen lainnya \\
$2,4,6,8$ & Nilai-nilai antara dua nilai pertimbangan yang berdekatan \\
Kebalikan & Jika aktivitas $i$ mendapat satu angka dibandingkan dengan aktivitas \\
& $j$, maka $j$ memiliki nilai kebalikannya dibandingkan dengan $i$ \\
\hline
\end{tabular}


Selanjutnya menghitung matriks perbandingan berpasangan (pairwise comparison matrix) sesuai dengan tabel nilai skala perbandingan berpasangan seperti berikut ini (Alonso, 2006):

$$
\left.A=\left[a_{i j}\right]=\begin{array}{ccc}
A_{1} & A_{2} & A_{n} \\
A_{1} & A_{2} \\
A_{n} & a_{12} & a_{1 n} \\
1 / a_{12} & 1 & a_{2 n} \\
1 / a_{1 n} & 1 / a_{2 n} & 1
\end{array}\right)
$$

a. Sintesis

Gambar 1. Pairwise Comparison Matrix

Hal-hal yang dilakukan adalah:

a. Merubah nilai perbandingan menjadi nilai desimal

b. Menjumlahkan nilai-nilai dari setiap kolom pada matriks

c. Membagi setiap nilai dari kolom dengan total kolom yang bersangkutan untuk memperoleh normalisasi matriks

d. Menjumlahkan nilai-nilai dari setiap baris

e. Menghitung nilai eign vector untuk setiap elemen/ kriteria, dengan rumus:

eign vector $=\frac{\text { jumlah baris }}{n}$

f. Menghitung nilai maksimum untuk setiap elemen/ kriteria, dengan rumus:

nilai maks $=$ jumlah kolom $*$ eign vector

g. Menjumlahkan nilai maksimum

h. Menghitung consistency index

(CI) dengan rumus:

$C I=\frac{\text { jumlah maksimum }-n}{n-1}$

dimana :

$\mathrm{n}$ = banyaknya elemen (kriteria)

i. Menghitung nilai consistency ratio $(C R)$ dengan rumus:

$C R=\frac{C I}{R I}$

$R I$ adalah tabel ratio index

TABEL 2.

RI (RATIO INDEX)

\begin{tabular}{cc}
\hline & RI \\
\hline 1 & 0,00 \\
2 & 0,00 \\
3 & 0,58 \\
4 & 0,9 \\
5 & 1,12 \\
6 & 1,24 \\
7 & 1,32 \\
8 & 1,41 \\
9 & 1,45 \\
10 & 1,49 \\
\hline
\end{tabular}

Perhitungan menggunakan tabel RI menyesuaikan dengan jumlah elemen/ kriteria. Apabila jumlah elemen/ kriteria adalah 3, maka nilai CI dibagi dengan 0,58 . Dalam hal ini berlaku aturan bahwa jumlah kriteria minimum 3 , karena jika hanya 2 maka akan berpengaruh terhadap nilai $C R$.

Antivirus: Jurnal Ilmiah dan Teknik Informatika, November 2016, Vol.10, No. 2 
j. Apabila CR matriks $<0,1$ berarti nilai matriks konsisten. Apabila CR matriks $>$ 0,1 berarti nilai matriks tidak konsisten. Perlu dilakukan penggantian nilai pada matriks berpasangan (Kusrini, 2007).

\section{Metode PENELITIAN}

\section{a. Lokasi Penelitian}

Tempat yang digunakan untuk penelitian di Fakultas Teknologi Informasi (FTI) Universitas Islam Balitar. Waktu penelitian mulai dari bulan Maret 2016 sampai dengan bulan Agustus 2016.

\section{b. Metode Perancangan Sistem}

\section{Data Flow Diagram (DFD)}

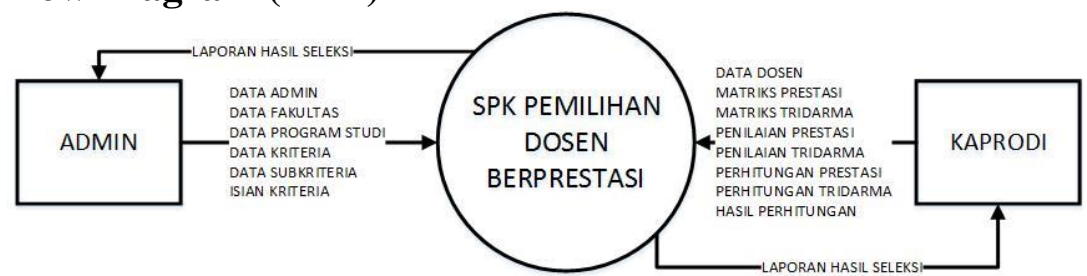

Gambar 2. Data Flow Diagram (DFD) Level 0

Gambar 2 menjelaskan alur dari sistem pemilihan dosen berprestasi. User/ pengguna sistem admin memasukkan data admin yang terdiri dari admin dan kaprodi untuk membedakan hak akses saat login ke dalam sistem. Kemudian memasukkan data fakultas, data program studi, data kriteria, data subkriteria dan isian kriteria. Selanjutnya kaprodi dapat memasukkan data dosen, matriks berpasangan untuk kriteria prestasi unggul dan karya tridarma, penilaian prestasi dan tridarma, perhitungan nilai dosen untuk kriteria prestasi unggul dan karya tridarma serta hasil perhitungan yang merupakan hasil dari pemilihan dosen berprestasi. Laporan dari hasil dari pemilihan dosen berprestasi dapat dilihat oleh admin dan kaprodi.

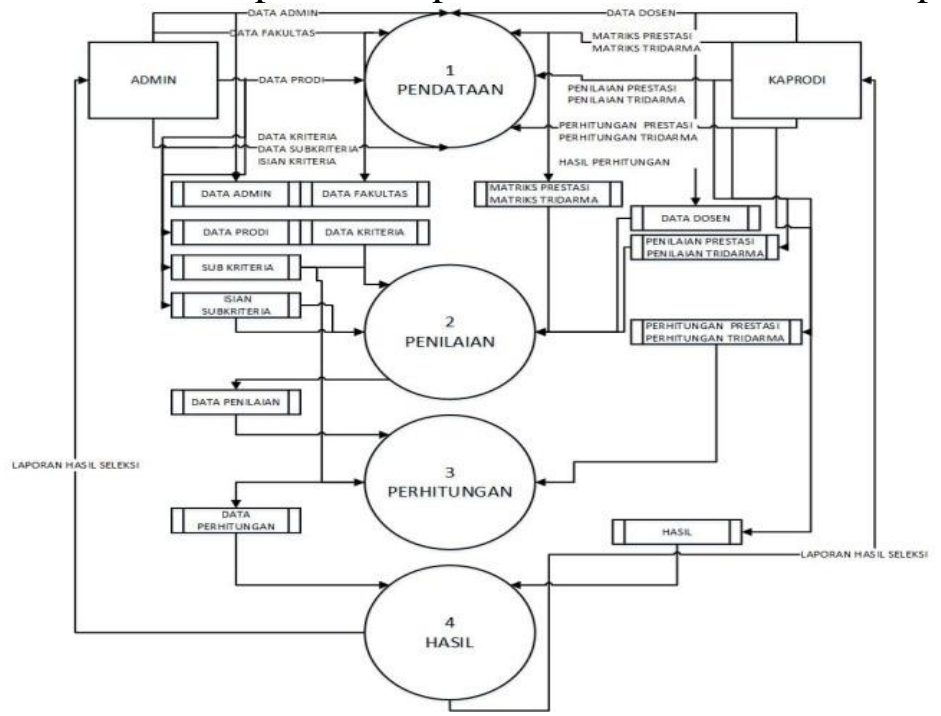

Gambar 3. Data Flow Diagram (DFD) Level 1 
Selanjutnya pada gambar 3, proses pendataan admin memasukkan data admin, data fakultas, data program studi, data data kriteria, data subkriteria dan isian subkriteria. Kaprodi memasukkan data dosen, matriks berpasangan dan penilaian prestasi dan tridarma.

Proses kedua adalah penilaian. Proses penilaian mengolah data subkriteria, isian subkriteria, penilaian prestasi dan penilaian tridarma untuk masing-masing dosen. Hasil dari proses penilaian, akan berlanjut pada proses perhitungan. Perhitungan data penilaian dengan matriks berpasangan serta nilai dari data subkriteria. Hasil dari proses perhitungan, akan berlanjut pada proses hasil. Hasil dari proses perhitungan, akan dihitung dengan nilai dari data kriteria untuk masing-masing dosen. Hasil dari proses ini adalah laporan hasil seleksi, bisa dilihat oleh admin dan kaprodi.

\section{HASIL DAN PEMBAHASAN}

\section{a. Implementasi Sistem} berikut :

Sistem pemilihan dosen berprestasi yang penulis rancang ini berjalan sebagai

a. Admin bisa memasukkan data fakultas dan program studi Unisba

b. Admin bisa memasukkan data kriteria, subkriteria dan isian kriteria

c. Kaprodi bisa memasukkan data dosen yang ikut serta dalam pemilihan dosen berprestasi

d. Kaprodi bisa memasukkan nilai matriks prestasi dan tridarma

e. Kaprodi bisa memasukkan data penilaian prestasi dan tridarma

f. Kaprodi bisa memasukkan data perhitungan prestasi dan tridarma

g. Kaprodi bisa memasukkan data hasil perhitungan

h. Admin dan kaprodi bisa mencetak hasil perhitungan

\section{b. Tampilan Sistem}

\section{Halaman Login}

Login merupakan pemberian hak akses terhadap menu-menu berikutnya, sehingga setiap user/ pengguna memiliki keterbatasan dalam mengakses menu-menu yang disajikan. Berikut ini tampilan halaman login:
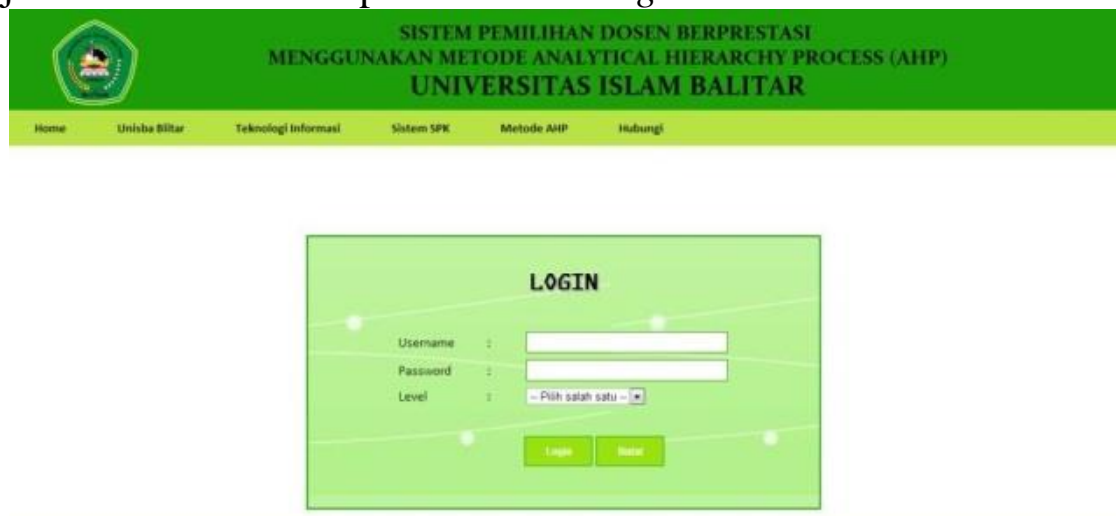

Gambar 4. Halaman Login

Antivirus: Jurnal Ilmiah dan Teknik Informatika, November 2016, Vol.10, No. 2 


\section{Halaman Menu Matriks}

Halaman menu matriks pada gambar 5 merupakan penerapan dari metode Analytical Hierarchy Process (AHP). Pembuatan matriks perbandingan berpasangan pada prestasi unggul mempunyai 3 subkriteria yaitu prestasi penelitian, pendidikan dan pengabdian. Sedangkan pada karya tridarma mempunyai 4 subkriteria yaitu penelitian, pendidikan, pengabdian dan penunjang Berikut ini tampilan halaman Menu Matriks:

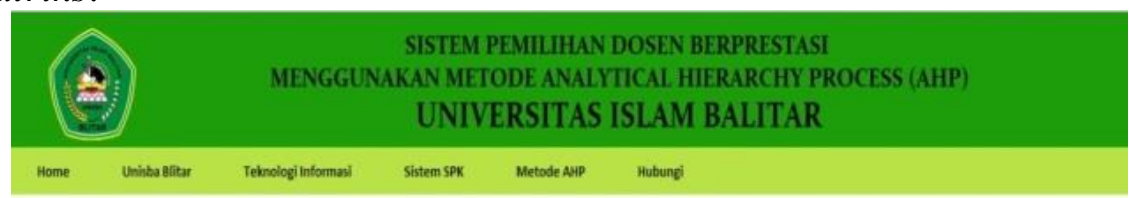

Hallo "kaprodi"

MATRIKS PRESTASI BERPASANGAN

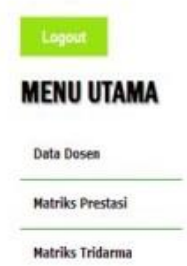

\begin{tabular}{|c|c|c|c|c|}
\hline Prestail & Pratasi Ponelitian & Prestai Pendidlian & Pratasi Pengabdian & Hapus \\
\hline Prestasi Penelitian & 1 & 3 & 6 & Havis \\
\hline Prestasi Pendidian & $1 / 3$ & 1 & 4 & Hagus \\
\hline Prestasi Pengabdian & $1 / 6$ & $1 / 4$ & 1 & Hagus \\
\hline
\end{tabular}

Gambar 5. Halaman Menu Matriks Prestasi

\section{Halaman Menu Hasil Pemilihan Dosen Berprestasi}

Hasil penilaian menampilkan rating nilai yang merupakan nilai hasil dari pemilihan dosen berprestasi. Berikut ini tampilan halaman menu hasil pemilihan dosen berprestasi:

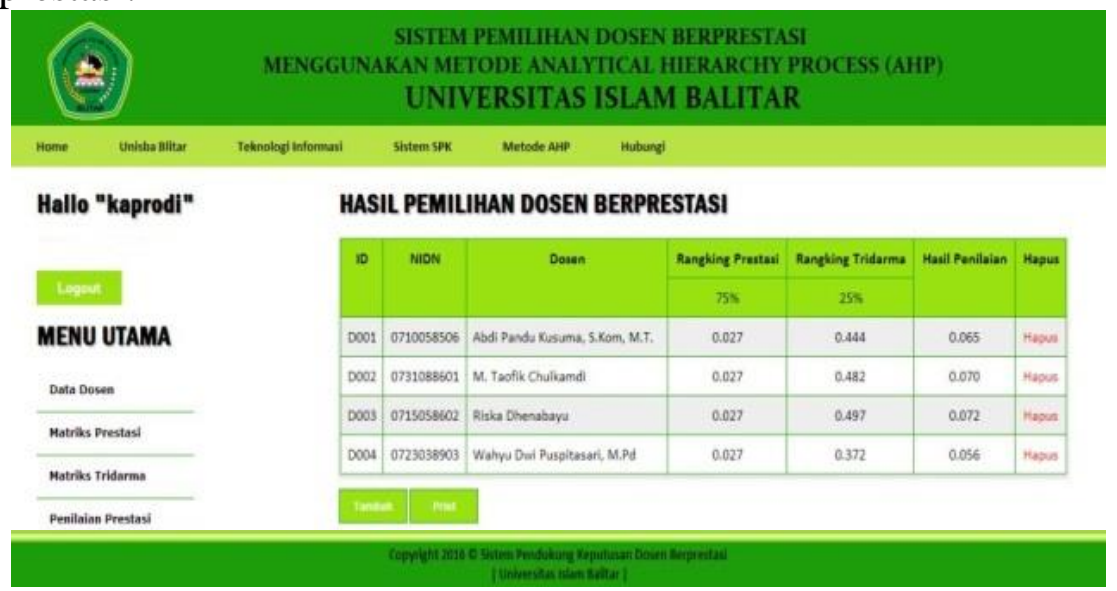

Gambar 6. Halaman Menu Hasil Pemilihan Dosen Berprestasi 


\section{Pengujian Sistem}

\section{1). Pengujian Black Box}

Pengujian black box menitikberatkan pada fungsi sistem. Metode ini digunakan untuk mengetahui apakah perangkat lunak berfungsi dengan benar atau tidak. Pengujian black box seperti pada tabel 3:

TABEL 3.

PENGUJIAN BLACK BOX

\begin{tabular}{llc}
\hline \multicolumn{1}{c}{ Kelas Uji } & Butir Uji & Jenis Pengujian \\
\hline Menu login & Login ke sistem dengan level yang berbeda & Black box \\
\hline & Pengisian data admin & Black box \\
& Pengisian data fakultas & Black box \\
Pengisian Data & Pengisian data program studi & Black box \\
Master & Pengisian data kriteria & Black box \\
& Pengisian data subkriteria & Black box \\
& Pengisian data isian kriteria & Black box \\
\hline & Pengisian data dosen & Black box \\
& Pengisian data matriks prestasi & Black box \\
Pengisian Data & Pengisian data matriks tridarma & Black box \\
Utama & Pengisian data penilaian prestasi & Black box \\
& Pengisian data penilaian tridarma & Black box \\
& Pengisian data perhitungan prestasi & Black box \\
& Pengisian data perhitungan tridarma & Black box \\
\hline Pengujian & Laporan hasil perhitungan dosen & Black box \\
Laporan & & \\
\hline
\end{tabular}

\section{2). Kuesioner Desain, Kesesuaian dan Kemudahan Sistem}

Berikut ini kuesioner tentang desain, kesesuaian dan kemudahan sistem:

TABEL 4.

KUESIONER DESAIN SISTEM

\begin{tabular}{|c|c|c|c|c|c|}
\hline No & Pertanyaan & \multicolumn{4}{|c|}{ Penilaian } \\
\hline A. & Pertanyaan/ pernyataan tentang Desain Sistem & SS & $\mathbf{s}$ & B & $\mathbf{K}$ \\
\hline 1 & Tampilan awal sistem sangat bagus & & & & \\
\hline 2 & Desain dan warna yang dipakai sangat bagus & & & & \\
\hline 3 & Tampilan antar muka sistem yang menarik & & & & \\
\hline 4 & Menu yang ada di sistem mudah difahami & & & & \\
\hline 5 & Penataan menu di sistem sudah bagus & & & & \\
\hline 6 & Tampilan halaman sistem sudah sesuai dengan yang diinginkan & & & & \\
\hline 7 & Penggunaan kata dan bahasa yang mudah difahami & & & & \\
\hline 8 & Penggunaan tabel dalam sistem sangat membantu & & & & \\
\hline 9 & Hasil akhir dapat menampilkan rating nilai dari pemilihan dosen & & & & \\
\hline 10 & $\begin{array}{l}\text { Fitur cetak pada sistem membantu untuk menampilkan laporan hasil } \\
\text { dari sistem }\end{array}$ & & & & \\
\hline
\end{tabular}

Pada tabel 4 ditampilkan hasil kuisioner berdasarkan penilaian terhadap desain sistem pada aplikasi sistem pendukung keputusan pemilihan dosen berprestasi. 
TABEL 5.

KUESIONER KESESUAIAN SISTEM

\begin{tabular}{|c|c|c|c|c|c|}
\hline B. & Pertanyaan/ pernyataan tentang Kesesuaian Sistem & SS & $\mathbf{s}$ & B & $\mathbf{K}$ \\
\hline 1 & Sistem berfungsi sesuai dengan yang diinginkan & & & & \\
\hline 2 & Sistem bisa membantu dalam proses pemilihan dosen & & & & \\
\hline 3 & Menu-menu yang ada sudah sesuai dengan kebutuhan & & & & \\
\hline 4 & Menu yang ada sudah berfungsi dengan baik & & & & \\
\hline 5 & Informasi yang ditampilkan sudah sesuai dengan yang diinginkan & & & & \\
\hline 6 & Tombol di sistem sudah berfungsi dengan baik & & & & \\
\hline 7 & Metode AHP dalam sistem sudah bisa berjalan dengan baik & & & & \\
\hline 8 & Tampilan sistem sesuai dengan kebutuhan pengguna & & & & \\
\hline 9 & Proses input data, update, dan delete sudah berfungsi dengan baik & & & & \\
\hline 10 & Hasil akhir yang ditampilkan cukup akurat & & & & \\
\hline
\end{tabular}

Pada tabel 5 ditampilkan hasil kuisioner berdasarkan penilaian terhadap kesesuaian sistem pada aplikasi sistem pendukung keputusan pemilihan dosen berprestasi.

TABEL 6.

KUESIONER KEMUDAHAN SISTEM

\begin{tabular}{|c|c|c|c|c|c|}
\hline C. & Pertanyaan/ pernyataan tentang Kemudahan Sistem & SS & $\mathbf{s}$ & $\mathbf{B}$ & $\mathbf{K}$ \\
\hline 1 & Sistem ini mudah digunakan & & & & \\
\hline 2 & Sistem ini mudah dipelajari & & & & \\
\hline 3 & Sistem ini mudah difahami & & & & \\
\hline 4 & Sistem ini bisa diakses dengan mudah & & & & \\
\hline 5 & Halaman login bisa diakses dengan mudah & & & & \\
\hline 6 & Menu yang ada mudah difahami & & & & \\
\hline 7 & Proses input data mudah & & & & \\
\hline 8 & Sistem ini bisa membantu dalam pemilihan dosen & & & & \\
\hline 9 & Hasil akhir bisa diakses dengan mudah & & & & \\
\hline 10 & $\begin{array}{l}\text { Menurut anda, apakah hasil yang ditampilkan sudah sesuai dengan } \\
\text { keinginan anda? }\end{array}$ & & & & \\
\hline
\end{tabular}

Pada tabel 6 ditampilkan hasil kuisioner berdasarkan penilaian terhadap kemudahan sistem pada aplikasi sistem pendukung keputusan pemilihan dosen berprestasi.

Keterangan:

SS/ Sangat Baik $\quad=40$

$\mathrm{B} /$ Cukup $\quad=20$

S/ Baik $\quad=30$

K/ Kurang $\quad=10$

Berdasarkan dasar teori perhitungan metode pengujian beta, maka rumus untuk mencari persentase jawaban responden adalah sebagaimana yang dikemukakan oleh Wahyu Winarno (2010) sebagai berikut:

Persentase $=\frac{\text { Jumlah }}{\text { Total Jumlah }} \times 100 \%$ 
Hasil kuesioner terhadap 6 orang responden seperti pada tabel 7 berikut:

TABEL 7. HASIL KUESIONER

\begin{tabular}{lcccc}
\hline \multicolumn{1}{c}{ Aspek } & SB & B & C & K \\
\hline Desain Sistem & $41,2 \%$ & $58,8 \%$ & $0 \%$ & $0 \%$ \\
\hline Kesesuaian Sistem & $33,7 \%$ & $66,3 \%$ & $0 \%$ & $0 \%$ \\
\hline Kemudahan Sistem & $23,6 \%$ & $71 \%$ & $5,4 \%$ & $0 \%$ \\
\hline
\end{tabular}

\section{SIMPULAN}

\section{a. Kesimpulan}

Sistem pendukung keputusan pemilihan dosen berprestasi di Fakultas Teknologi Informasi Universitas Islam Balitar dibuat berbasis web dan dirancang untuk mengikuti pemilihan dosen berprestasi yang diadakan oleh Kopertis Wilayah VII. Sistem pemilihan dosen berprestasi menggunakan metode Analytical Hierarchy Process (AHP) dilakukan dengan membuat nilai matriks berpasangan untuk masingmasing kriteria. Nilai dari matriks berpasangan hasilnya harus konsisten. Data penilaian dosen akan dihitung dengan nilai matriks berpasangan dan hasil dari perhitungan tersebut akan muncul berbentuk rating nilai. Rating nilai dosen yang tertinggi, berhak untuk menjadi dosen berprestasi di Universitas Islam Balitar.

Hasil implementasi sistem pendukung keputusan pemilihan dosen berprestasi di Fakultas Teknologi Informasi Universitas Islam Balitar berdasarkan data kuesioner untuk desain sistem menunjukkan hasil yang baik dengan mendapatkan nilai persentase 58,8\%, kesesuaian sistem menunjukkan hasil yang baik dengan mendapatkan nilai persentase yang lebih tinggi yaitu 66,3\% dan pengguna tidak mengalami kesulitan dalam menggunakan sistem sesuai dengan nilai persentase kemudahan sistem yang paling tinggi yaitu $71 \%$. Hasil dari kuisioner secara keseluruhan mendapatkan hasil yang baik, menunjukkan sistem sudah sesuai dengan yang diharapkan. Sistem pemilihan dosen yang dibuat bebas dari kesalahan sintaks dan secara fungsional mengeluarkan hasil sesuai dengan yang diharapkan.

\section{b. Saran}

Sistem pendukung keputusan pemilihan dosen berprestasi ini memiliki beberapa kekurangan, oleh karena itu perlu pengembangan sistem lebih lanjut antara lain sebagai berikut:

1. Penentuan kriteria pemilihan dosen berprestasi disesuaikan dengan kondisi dan kebutuhan dari tempat penelitian sehingga kriteria yang digunakan tidak terlalu banyak

2. Penentuan perbandingan matriks berpasangan menggunakan metode Analytical Hierarchy Process (AHP) harus berdasarkan tempat penelitian

3. Penentuan aspek penilaian dosen harus berdasarkan tempat penelitian sehingga hasil pemilihan dosen berprestasi lebih akurat 
4. Aspek penilaian dosen sebaiknya tidak terlalu banyak sehingga sistem akan lebih mudah difahami dan dipelajari

5. Proses input data penilaian dosen sebaiknya dibuat dengan memasukkan data untuk masing-masing kriteria dalam form yang berbeda sehingga bisa lebih mudah

\section{DAFTAR PUSTAKA}

Asfi, Marsani., Sari, R.P., 2010. Sistem Penunjang Keputusan Seleksi Mahasiswa Berprestasi Menggunakan Metode Analytic Hierarchy Process (AHP). Jurnal Informatika. Vol. 6: No.2.

Atika, Linda. 2010. Sistem Penunjang Keputusan Penilaian Kinerja Pemilihan Dosen Berprestasi Menggunakan Metode Analytic Hierarchy Process (AHP). Jurnal Imiah MATRIK. Vol. 12: No.3.

Eniyati, Sri \& Santi, R.C.N., 2010. Perancangan Sistem Pendukung Keputusan Penilaian Prestasi Dosen Berdasarkan Penelitian dan Pengabdian Masyarakat. Jurnal Teknologi Informasi DINAMIK. Vol. XV: No.2.

Mufizar, Teuku. 2015. Sistem Pendukung Keputusan Pemilihan Dosen Berprestasi di STMIK Tasikmalaya Menggunakan Metode Simple Additive Weighting (SAW). CSRID Journal. Vol.7: No.3.

Widaningsih, Sri. 2010. Sistem Pendukung Keputusan Penentuan Dosen Pembimbing Kerja Praktek Dengan Metode Analytical Hierarchy Process (AHP) Model Rating. Jurnal Informatika. Vol.7: No.01.

Yusuf, M.A., Hutabarat, P.B., Pibriana, D., 2016. Perbandingan Sistem Pendukung Keputusan Menggunakan Metode SAW (Simple Additive Weighting) dan AHP (Analytic Hierarchy Process). Jurnal Teknik Informatika.

Idris, S.A.L., 2014. Penentuan Penerima Bantuan Modal Wirausaha Baru Pada Dinas Koperasi Perindustrian dan Perdagangan Provinsi Gorontalo. Skripsi. Tidak dipublikasikan. Gorontalo: Universitas Negeri Gorontalo.

Sinaga, Johannes. 2009. Penerapan Analytical Hierarchy Process (AHP) Dalam Pemilihan Perusahaan Badan Usaha Milik Negara (BUMN) Sebagai Tempat Kerja Mahasiswa Universitas Sumatera Utara (USU). Skripsi. Tidak dipublikasikan. Sumatera Utara: Universitas Sumatera Utara.

Winarno, Wahyu. 2010. Sistem Pendukung Keputusan Penilaian Karyawan untuk Menempati Suatu Jabatan berdasarkan Spesifikasi Five-Fold Grading Sistem. Skripsi. Tidak dipublikasikan. Bandung: UNIKOM.

Amborowati, Armadyah. 2007. Pengantar Pemrograman Terstruktur. Yogyakarta: Penerbit Andi.

Arbie. 2004. Manajemen Database dengan MySQL. Yogyakarta: Penerbit Andi.

Kadir, Abdul. 2003. Pemrograman Web Mencakup HTML, CSS, JavaScript, \& PHP. Yogyakarta: Penerbit Andi.

Kadir, Abdul. 2008. Dasar Pemrograman Web Dinamis Menggunakan PHP. Yogyakarta: Penerbit Andi.

Kusrini. 2007. Konsep dan Aplikasi Sistem Pendukung Keputusan. Yogyakarta: Penerbit Andi. 
Saaty, T. L. 1980. The Analytic Hierarchy Process, Planning, Piority Setting, Resource Allocation. New York: McGraw-Hill Companies.

Turban, Efraim., Aronson, Jay E., Liang, Ting-Peng., 2001. Decision Support Systems and Intellgient Systems. 6 th edition. Prentice Hall: Upper Saddle River, NJ.

Turban, Efraim., Aronson, Jay E., Liang, Ting-Peng., 2005. Sistem Pendukung Keputusan dan Sistem Cerdas. Yogyakarta: Penerbit Andi.

Wicaksono, Yogi. 2008. Membangun Bisnis Online dengan Mambo. Jakarta: PT. Elex Media Komputindo.

Kementerian Riset Teknologi dan Pendidikan Tinggi Direktorat Jenderal Pendidikan Tinggi Direktorat Pendidik dan Tenaga Kependidikan, 2015.

Undang-undang No 14 tahun 2005 tentang Guru dan Dosen.

Kusnadi, Eris. 2012. Tree diagram atau diagram pohon. (https://eriskusnadi.wordpress.com/2012/01/30/tree-diagram-atau-diagrampohon/ diakses pada 11 September 2016).

Permana, Bayu D.A. 2014. Fungsional Dari Notepad++. (https://bayudwiarta.wordpress.com/2014/10/16/fungsional-dari-notepad/, diakses pada 19 Agustus 2016). 